\title{
TOZ METALURJİSİ YÖNTEMİYLE ÜRETİLEN AISi7 KÖPÜKLERİN DÜŞÜK HIZLI DARBE ENERJİLERİ ALTINDA PENETRASYON DAVRANIŞININ ÍNCELENMESİ
}

\author{
*Henifi ÇiNIĊ, **Uğur GÖKMEN, ***Arif UZUN, ****Halil KARAKOÇ, \\ *****Ceren GÖDE, *Mehmet TÜRKER \\ *Gazi Ü. Teknoloji Fakültesi Metalurji ve Malzeme Müh. Beşevler, ANKARA \\ **Gazi Ü. Atatürk Meslek Yüksekokulu Çubuk, ANKARA \\ ***Kastamonu Ü. Cide Rıfat Ilgaz Meslek Yüksekokulu Cide, KASTAMONU \\ ****Hacettepe Ü. Hacettepe Ankara Sanayi Odası 1.OSB Meslek YüksekOkulu, ANKARA \\ *****Pamukkale Ü. Denizli Teknik Bilimler Meslek Yüksekokulu, DENIZLİ \\ hcinici@gazi.edu.tr, ugurgokmen@gazi.edu.tr, auzun@kastamonu.edu.tr, \\ halil.karakoc@hacettepe.edu.tr, cgode75@gmail.com, mturker@gazi.edu.tr
}

(Geliş/Received: 21.12.2012; Kabul/Accepted: 15.05.2014)

ÖZET

Bu çalışmada AlSi7 köpüklerin düşük hızlı darbe enerjileri altındaki penetrasyon davranışları incelenmiştir. Bu amaçla toz metalurjisi yöntemi ile üretilen $55 \times 55 \times 20 \mathrm{~mm}$ boyutlarında Al köpüklere ağırlık düşürme test cihazı kullanarak farklı hızlarda $\left(1,2-3 \mathrm{~ms}^{-1}\right)$ darbeler uygulanmıştır. Bir numune üzerinde delinme meydana gelene kadar yapılan darbe testleri ile saplanma ve delinme darbe davranışları incelenmiştir. Darbe sonrası numunelerin içyapılarında meydana gelen değişiklikler makro boyutta incelenmiştir.

Anahtar kelimeler: Darbe enerjisi, alüminyum köpük, toz metalurjisi

\section{INVESTIGATION OF THE PENETRATION BEHAVIOR OF AISi7 FOAM, PRODUCED BY POWDER METALLURGY METHOD, UNDER LOW-VELOCITY IMPACT ENERGIES}

\begin{abstract}
In this study, the impact behaviors of AlSi7 foams under low-velocity impact energies were investigated. The low-velocity impacts $\left(1,2-3 \mathrm{~ms}^{-1}\right)$ were applied to the samples with $55 \times 55 \times 20 \mathrm{~mm}$ dimensions using the weight drop test machine. The impact tests were performed until perforation took place on a sample and so penetration and perforation impact behavior were analyzed. The changes in the internal structures of the samples after the impact were observed in the macro level.
\end{abstract}

Keywords: Impact energy, aluminum foam, powder metallurgy

\section{GIRISŞ (INTRODUCTION)}

Metalik köpükler, yapısal sandviç paneller ve enerji sönümleme araçları için potansiyel malzemelerdir. Bu malzemeler hava ve uzay araçlarında, otomobillerde hatta biyomedikal protez uygulamalarında bile kullanılabilmektedir [1]. Özellikle enerji absorbe özelliği ele alındığında, otomobil ve trenlerde çarpışma ihtimali yüksek bölgelerdeki maksimum çarpma enerjisi dağıtılarak deformasyonu kontrol etmek mümkün olabilir [2]. Spesifik bir uygulama alanı olarak, Al esaslı metalik köpüğün darbe emme özelliği sebebi ile integral zırh malzemesi üretiminde kullanılması konusunda yoğun çalışmalar yapılmaktadır. Alüminyum köpüğün gözenekli yapısı gerilme dalgalarını dağıtır ve ince dalgalar olarak hareket ettirir [3]. Metal matrisli köpükler, üretim teknolojilerinin geliştirilmesi ile şu an çok daha düşük maliyetle elde edilebilmektedir. Bu gelişmelere bağlı olarak metalik köpüklerin morfolojik ve mikro yapısal özellikleri ile ilgili mekanik davranışların belirlenmesine yönelik önemli çalışmalar mevcuttur 
[1, 4-8]. Alüminyum köpüklerin düşük ve yüksek darbe yükleri altında enerji sönümleme kapasitelerini incelemek amacıyla farklı çalışmalar yapılmıştır [911]. Örneğin metalik köpüklerin statik girinti ve penetrasyon özelliklerinin belirlenmesi üzerine yapılan çalışmalarda köpüğün yalnızca delici ucun temas ettiği bölgede plastik deformasyona uğradığ belirtilmiştir [8, 12]. Ramachandra ve Li tarafından yapılan çalışmalarda penetrasyon direncinin 10 $\mathrm{m} / \mathrm{s}$ 'den daha büyük hızlarda artığ 1 belirtilmiştir [13, 14]. Lua ve arkadaşları darbe hızının absorbe edilen toplam enerji ve bölgesel deformasyon üzerinde etkili olduğunu belirtmiştir [15]. Kumar ve arkadaşları küresel ve düz uçlu deliciler kullanarak köpüğün enerji sönümleme ve bölgesel hasar direncini belirlemeyi amaçlamıştır [16]. Peroni ve arkadaşları yaptıkları çalışmada iki farklı yoğunluğa sahip (150 $\mathrm{kg} / \mathrm{m}^{3}$ ve $300 \mathrm{~kg} / \mathrm{m}^{3}$ ) kapalı hücreli Al köpüğe SHPB (Split Hopkinson Pressure Bar) tekniği uygulayarak gerilme oranının yoğunluğa bağlı değişimini incelemişlerdir. Araştırmacılar uygulanan gerinim hassasiyetinin yoğunluktan bağımsız değerlendirilemeyeceğini bildirmiştir [17].

$\mathrm{Bu}$ çalışmada düşük darbe hızlarında $\left(<10 \mathrm{~ms}^{-1}\right)$ alüminyum köpüğün penetrasyon davranışı incelenmiştir. Toz metalurjisi yöntemi ile üretilen AlSi7 esaslı kapalı gözenekli köpüklere ağırlık düşürme test cihazı kullanarak farklı hızlarda (1,2 - 3 $\mathrm{ms}^{-1}$ ) darbeler uygulanmıştır. Numune üzerinde delinme meydana gelene kadar yapılan darbe testleri ile saplanma ve delinme darbe davranışları incelenmiştir. Darbe sonrası numunelerin içyapılarında meydana gelen değişiklikler makro boyutta incelenmiştir.

\section{DENEYSEL ÇALIŞMA VE METODOLOJI (EXPERIMENTAL AND METHODOLOGY)}

\subsection{Deney Numuneleri (Materials)}

Yapılan çalışmada toz metalurjisi yöntemi ve ikincil işlemler (ekstrüzyon, haddeleme) kullanılarak Al matrisli metalik köpükler üretilmiştir. Matris malzemesi olarak Ecka Granules firması tarafindan üretilen \% 99,9 saflıktaki saf Al tozu, Sigma Aldrich firması tarafindan üretilen $\mathrm{Si}$ tozu ve köpürtücü madde olarak üretilen $\% 98$ saflıktaki $\mathrm{TiH}_{2}$ tozu kullanılmıştır. Kullanılan tozların fiziksel özellikleri Tablo 1' de verilmiştir.

\subsection{Metod (Methodology)}

\subsubsection{Alüminyum köpük üretimi \\ (Production of Aluminum Foam)}

Al tozuna \% 7 oranında $\mathrm{Si}$ ve $\% 0,8$ oranında $\mathrm{TiH}_{2}$ tozları eklenerek, üç boyutlu turbula marka T2F tipi karıştırıcıda karıştırılmıştır. Karışım tozlar, kalıp içerisinde $600 \mathrm{MPa}$ basınç altında tek yönlü preslenerek ham yoğunlukta silindirik blok numuneler üretilmiştir. Elde edilen blok numuneler Protherm marka firın içerisinde ön ssitma amacı ile $500^{\circ} \mathrm{C}$ sicaklikta tutulduktan sonra ekstrüzyon ve haddeleme işlemlerine tabi tutularak köpürtme öncesi preform numuneler haline getirilmiştir.

Üretilen Al matrisli kompozit köpüklerde köpürtme sıcaklığının gözenek morfolojilerine etkilerini incelemek ve uygun köpürtme sıcaklığını tespit etmek amaciyla farklı sicaklıklarda pilot deneyler yapılmıştır. Yapılan pilot deneylerde literatüre [18] paralel olarak 5 farklı köpürtme sicaklığ 1 belirlenmiştir (Tablo 2).

Köpürtme sıcaklığının gözenek morfolojisine ve elde edilen köpük numunenin yoğunluğuna etkilerini belirlemek amaciyla Tablo 2'de belirtilen köpürtme sıcaklıkları preform numunelere uygulanmıştır. AlSi7 karışımı için uygun köpürtme sıcaklığ $170^{\circ} \mathrm{C}$ olarak belirlenmiştir. Köpürtme işlemleri $10{ }^{\circ} \mathrm{C} / \mathrm{dk}$ isıtma hızına sahip SFL marka Mufle tipi fırın içerisinde koruyucu atmosfer kullanılmadan gerçekleştirilmiştir. Köpürtme işlemi $55 \times 55 \times 20 \mathrm{~mm}$ boyutlarında kalıp içerisinde yapılmıştır.

Tablo 1. Deneylerde kullanılan tozların fiziksel özellikleri ve üretim yöntemleri (Physical properties and production methods of powders experimented)

\begin{tabular}{|c|c|c|c|c|}
\hline \multirow{2}{*}{$\begin{array}{c}\text { Toz } \\
\text { Malzeme }\end{array}$} & \multicolumn{4}{|c|}{ Fiziksel Özellikler } \\
\hline & Üretim yöntemi & $\begin{array}{c}\text { Ergime } \\
\text { sicaklığı }\left({ }^{\circ} \mathrm{C}\right)\end{array}$ & $\begin{array}{c}\text { Yoğunluk } \\
\left(\mathrm{g} / \mathrm{cm}^{3}\right)\end{array}$ & $\begin{array}{c}\text { Toz Boyutu } \\
(\mu \mathrm{m})\end{array}$ \\
\hline Alüminyum & $\begin{array}{c}\mathrm{Gaz} \\
\text { atomizasyon }\end{array}$ & 660 & 2,7 & $<160$ \\
\hline Si & $\begin{array}{c}\mathrm{Gaz} \\
\text { atomizasyon }\end{array}$ & 1410 & 2,34 & $<10$ \\
\hline $\mathrm{TiH}_{2}$ & --- & $<400$ & 3,91 & $<45$ \\
\hline
\end{tabular}


Tablo 2. Köpürtme sıcaklıkları (Foaming Temperature)

\begin{tabular}{|c|c|c|c|c|c|}
\hline $\begin{array}{c}\text { Matris } \\
\text { Malzemesi }\end{array}$ & \multicolumn{5}{|c|}{$\begin{array}{c}\text { Köpürtme Sicaklığı } \\
\left({ }^{\circ} \mathrm{C}\right)\end{array}$} \\
\hline AlSi7 & 650 & 670 & 690 & $\mathbf{7 1 0}$ & 730 \\
\hline
\end{tabular}

\subsection{Karakterizasyon (Characterization)}

\subsubsection{Yoğunluk Ölçümleri (Density Measurements)}

Üretilen köpük numunelerin yoğunlukları Sartorius marka terazi ve bu terazi ait yoğunluk kiti kullanılarak belirlenmiştir. Numunelerdeki gözenek yoğunluğu (boşluk miktarı) ise aşağıdaki şekilde hesaplanmıştır [19].

Gözenek yoğunluğu $=\frac{V-(m \div g)}{V} \times 100$

m: Numunenin ağırlığ

$\mathrm{g}$ : Ana malzemenin yoğunluğu

$\mathrm{V}$ : Köpüğün hacmi

\subsubsection{Darbe Testi (Impact Test)}

Darbe testlerinde Instron-Dynatup $9250 \mathrm{HV}$ darbe test cihazı kullanılmıştır (Şekil 1). Bu cihaz pnömatik bir sabitleyiciye, pnömatik geri sekme frenlerine, çapraz kafaya ve impuls veri yazılım sistemine sahiptir. Pnömatik geri sekme frenleri numuneler üzerine etkiyen tekrarlı darbeleri önlemektedir. Impuls veri yazılım sistemi ile maksimum yük $(\mathrm{kN})$, maksimum yüke ulaşma zamanı (ms), maksimum yükteki çökme miktarı (mm), toplam çökme miktarı (mm), darbe hızı $(\mathrm{m} / \mathrm{s})$, darbe enerjisi (J), absorbe edilen enerji $(\mathrm{J})$ takip edilebilir. Çapraz kafa ise ayarlanabilir ağırlık kütlelerine sahiptir ve düşük hızlı darbe çalışmalarında 12,7 mm çapında yarı küresel darbe ucu kullanılmıştır. Bu çalışmada darbe ucu ve üzerindeki ağırlıklarla beraber toplam ağırlık bütün darbe testleri için 6,32 kg'dır. Numunelere 1,2 $\mathrm{ms}^{-}$ 1'den delinmenin meydana geldiği $3 \mathrm{~ms}^{-1}$ hizlara kadar darbe testleri uygulanmıştır. Uygulanan darbe testleri sırasıyla; $1,2 \mathrm{~m} / \mathrm{s}$ için $0,0776(\mathrm{~m}), 1,8 \mathrm{~m} / \mathrm{s}$ için $0,1571(\mathrm{~m}), 2,1 \mathrm{~m} / \mathrm{s}$ için $0,2405(\mathrm{~m}), 2,8 \mathrm{~m} / \mathrm{s}$ için 0,4007 (m), $3 \mathrm{~m} / \mathrm{s}$ için 0,4827 (m).

\section{DENEYSEL SONUCLAR VE TARTISMA (EXPERIMENTAL RESULTS AND DISCUSSION)}

\subsection{Yoğunluk (Density)}

Yapılan deneysel çalıșmalar sonucunda, elde edilen bütün yoğunluk değerleri $1 \mathrm{~g} / \mathrm{cm}^{3}$ 'ün altındadır. Sabit köpürtücü madde $\left(\begin{array}{llll}\% & 0,8 & \mathrm{TiH}_{2}\end{array}\right)$ miktarında artan köpürtme sıcaklığ1 ile yoğunluğun azaldığ1 tespit edilmiştir. $\mathrm{Bu}$ durum, sicaklığın artmasına bağlı olarak meydana gelen gözenek duvar kalınlığındaki azalma ve gözenek hacminde ki artıştan kaynaklanmıştır. Şekil 2'de verilen grafikte görüldüğü gibi en fazla yoğunluk $650^{\circ} \mathrm{C}$ köpürtme sıcaklığında elde edilirken, en düşük yoğunluk değeri $730^{\circ} \mathrm{C}$ köpürtme sıcaklığında elde edilmiştir.

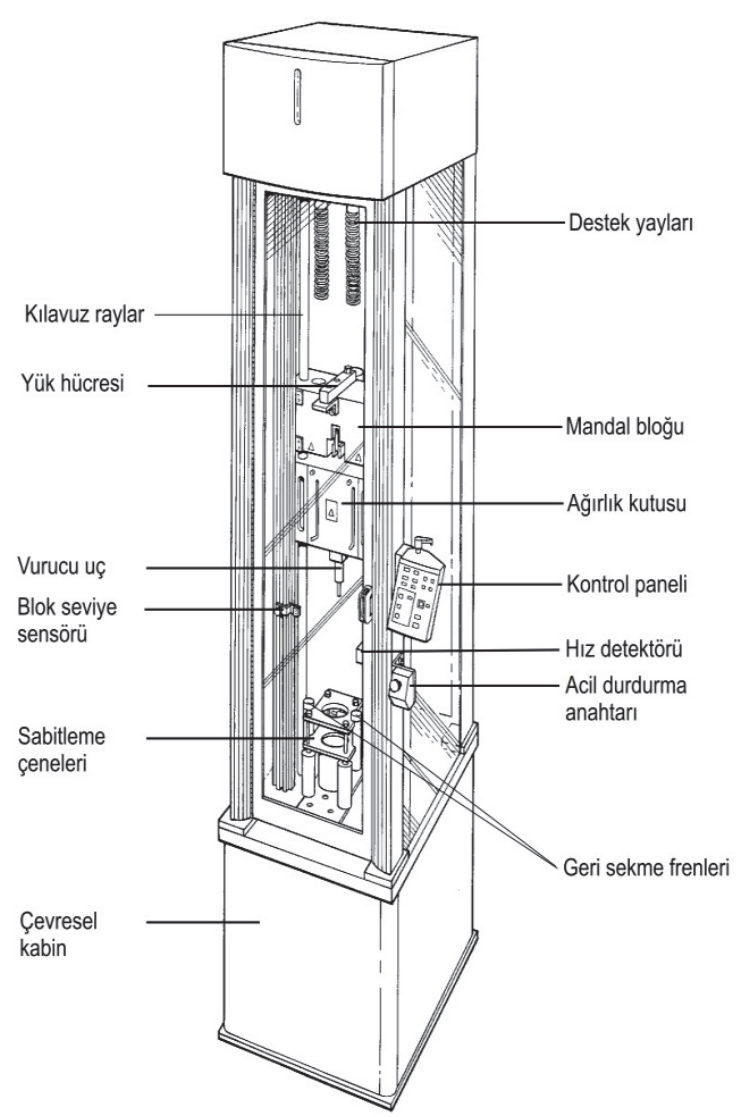

Şekil 1. Darbe test cihazı (Impact Tester) [20]

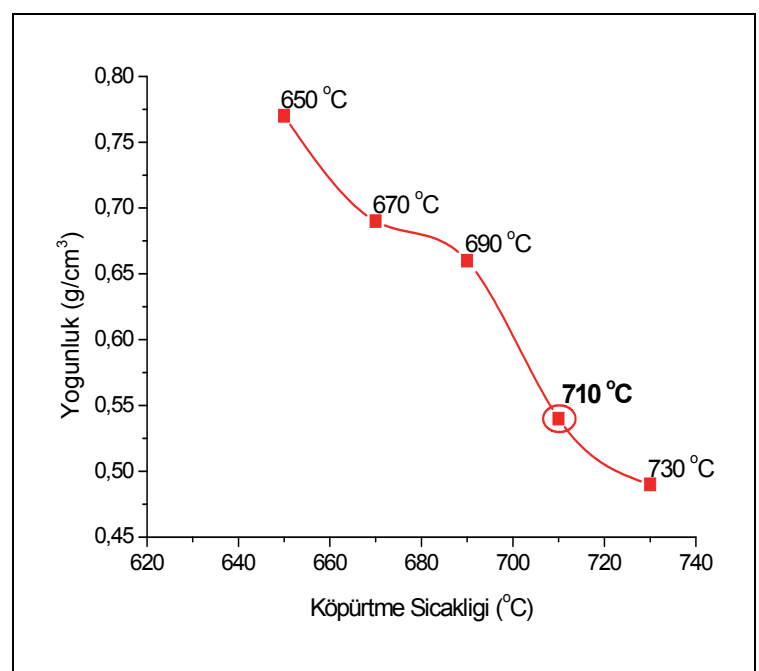

Şekil 2. Sıcaklık artışına bağlı olarak yoğunluk değișimi.

(Density variation depending on the temperature increase) 
Bütün köpürtme sıcaklıklarında aynı köpürtücü madde miktarlarında sıcaklık artışına bağlı olarak yoğunlukta bir azalma söz konusudur. Ancak, $730^{\circ} \mathrm{C}$ köpürtme sıcaklığında, $\mathrm{TiH}_{2}$ içerisinde ayrışan hidrojen miktarının ve yüksek sıcaklığın etkisiyle gözenek duvarlarında bozulma gözeneklerde birleşme olmuştur. Yüksek sicaklık, ergiyik metalin viskozitesini azaltmaktadır [21, 22]. Viskozitenin azalmasıyla gözenek üzerine etki eden drenaj etkisi azalacağından, gözenek içerisindeki hidrojen gazının basınc1, numune direncinden fazla olmakta ve gözenekler daha kolay büyümektedir [22]. Bozulma sonrası ise bazı numunelerin gözeneklerinde çökme meydana gelmiştir. Elde edilen yoğunluk değerlerine ve gözenek morfolojilerinin makro boyutta yapılan incelemelerine paralel olarak en uygun köpük numunelere $710^{\circ} \mathrm{C}$ sicaklıkta yapılan köpürtme işlemlerinde ulaşılmıştır. Darbe testlerinin yapılacağ $55 \times 55 \times 20 \mathrm{~mm}$ boyutundaki köpük numuneler bu sicaklıkta üretilmiştir.

\subsection{Kuvvet-Çökme (F-d) Eğrileri \\ (Force-deflection (F-d) Curves)}

Kuvvet-çökme (F-d) eğrileri, darbe olayı esnasında alüminyum köpüğün darbe davranışına ait çarpma ucunun numuneden geri sekmesi, numuneye saplanması ve delme gibi darbe davranışları hakkında bilgi vermektedir. Uygulanan bütün darbe enerjilerinde numune yüzeyinde çarpma ucu geri sekmezken, numuneye gömülmesi ve delme durumları gerçekleşmiştir. Şekil 3'te alüminyum köpüklerin saplanma ve delinme sinırlarına ait kuvvet-çökme eğrileri gösterilmiştir.

Darbe verileri +- $\% 2$ hata payına sahip Strain gauge/Piezo elektrik sensör ile ölçülmüştür. Şekil 3'te görüldüğü üzere $2,8 \mathrm{~ms}^{-1}$ hızlarda, $25 \mathrm{~J}$ darbe enerjisine kadar vurucu numunelere saplanırken, $30 \mathrm{~J}$ darbe enerjisinde ve $3 \mathrm{~ms}^{-1}$ darbe hızında alüminyum köpükte delinme meydana gelmiştir. Ancak bu bölgede çarpma ucu numuneyi tamamen delmemiştir. Dolayısıyla düşük hızlarda bu enerji seviyesi alüminyum köpük için sınır değeri olarak değerlendirilebilir. Çarpma ucunun numunelere saplanma durumunda her darbe enerjisi için kuvvetlerde ani düşüş gözlenmiştir. $\mathrm{Bu}$ durum, deformasyon esnasında gözeneklerin birbiri üzerine katlanması sonucu yoğunlaşmış bölgenin oluşmasından kaynaklanmıştır (Şekil 4).

Homojen dağılımlı gözenek yapısı içermeyen numunelerde artan darbe enerjisi ile maksimum temas kuvvetlerinde artış meydana gelmiştir. Maksimum kuvvet değerlerine ulaşıldıktan sonra numunelerde hasar oluşumu başlamış ve kuvvet eğrilerinde salınımlar meydana gelmiştir. Hasar oluşumu gözenek duvarlarında çatlama, kırılma ve eğilmeler şeklinde gerçekleşmiştir. Benzer hasar oluşumlarına literatürde rastlanmıştır [23]. Darbe hızı arttıkça hasar miktarı artmakta, böylece numunede hasara harcanan enerji miktarı da artmaktadır. Dikkat edilirse deformasyonun hemem hemen tamamı vurucunun alt kısmında meydana gelmiş ve yanal yayılma sergilememiştir. $\mathrm{Bu}$ durum alüminyum köpüklerin sergilediği sıfıra yakın Poisson oranı ile alakalı olabilir [16]. Deformasyon bölgesinin diğer bir karakteristik özelliği de çatlama, kırılma veya eğilme hattı içermesidir. Deforme olmuş numunelerde bu çizgi hatt1, vurucunun yan yüzeyine temas eden bölgelerdir. Shaw ve arkadaşları tarafından yapılan çalışmalarda izotropik hücresel malzemelerde benzer şekillerde deformasyon bölgelerinin oluştuğu gözlemlenmiştir [24].

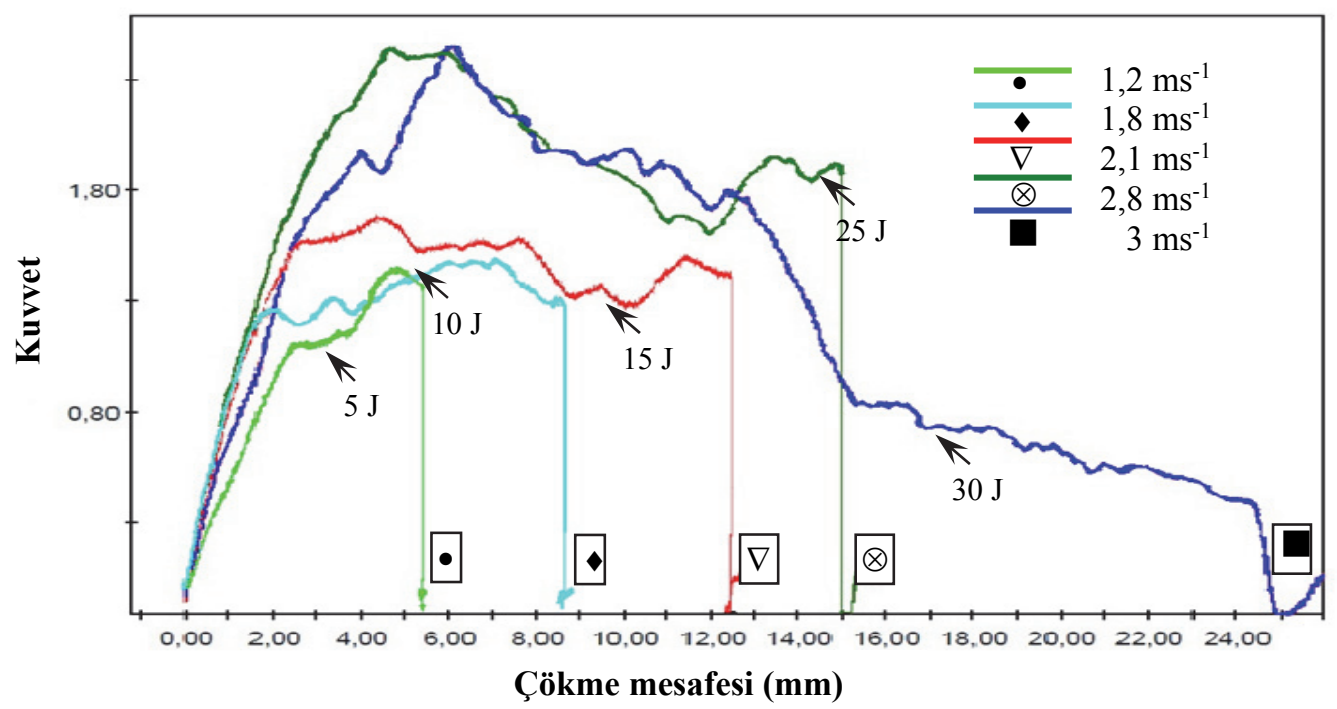

Şekil 3. Alüminyum köpük numunelere ait kuvvet-çökme eğrisi

(Force-deflection curves of aluminum foams) 


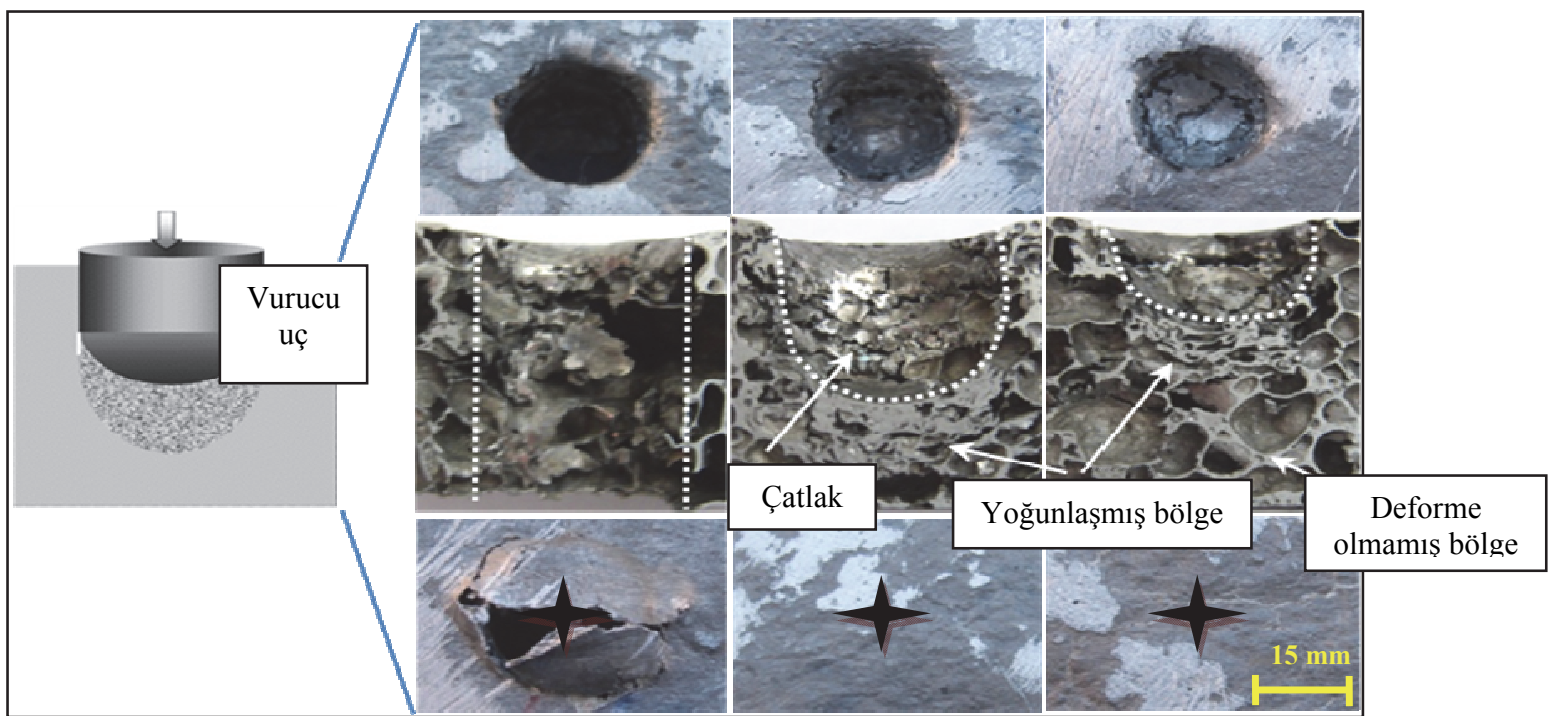

Şekil 4. Darbe testi sonucu deforme olan numunelerin makro yapı resimleri (Macrostructures of deformed samples after impact tests)

\subsection{Darbe karakteristikleri ve enerji profili (Impact characteristics and energy profile)}

Artan darbe enerjisine karşın alüminyum köpüklerin darbe cevaplarını anlamakta maksimum temas kuvveti ve süresi, toplam çökme miktarı, delinme ve saplanma durumları önemli darbe karakteristikleridir. Şekil 5 'te alüminyum köpüklerin enerji artışı ile darbe karakteristikleri ilişkisi verilmiştir.

Şekil 5'te artan darbe enerjisi ile toplam çökme miktarının belirgin şekilde arttığı görülmekte ancak, maksimum temas süresi için belirgin bir azalıs sadece ilk bölgede görülmektedir.

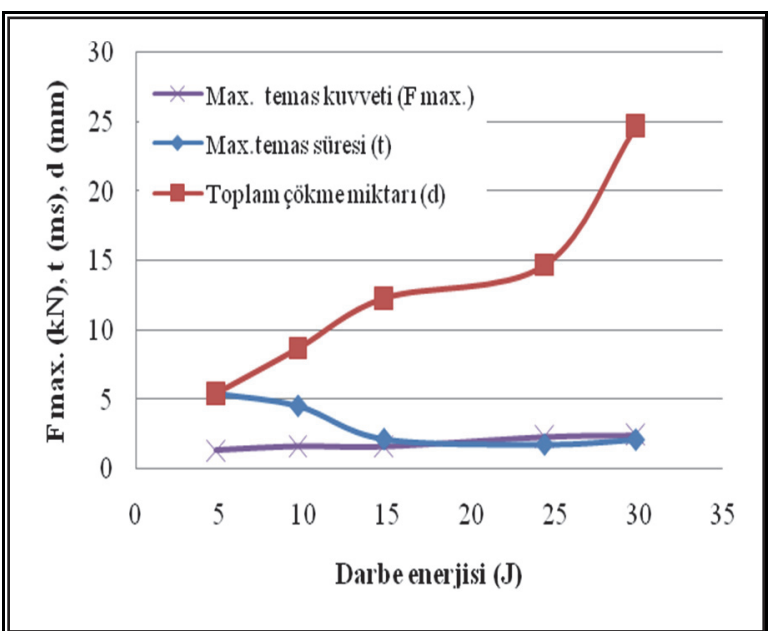

Şekil 5. Al köpüklerin enerji artışı ile darbe karakteristikleri ilişkisi

(Relationship between energy increase and impact characteristics of $\mathrm{Al}$ foams)

Benzer şekilde artan darbe enerjisi ile maksimum temas kuvvetinin de belirgin bir şekilde arttı̆̆ söylenemez. Alüminyum köpük uygulamalarında en önemli faktörlerden biri de bu malzemelerin enerji absorbe özelliğidir. Şekil 6'da alüminyum köpüklerin uygulanan farklı darbe enerjilerine karşı absorbe edilen enerji miktarları verilmiştir. Buna göre darbe enerjisi ve penetrasyon miktarındaki artış ile absorbe edilen enerji miktarı artmıştır. Darbe hızındaki artış ile metalik köpüklerin enerji absorbe kabiliyetlerinin arttığ1 diğer araştırmacılar tarafindan da belirtilmiştir $[13,14]$. Absorbe olan enerjinin darbe olayında malzeme tarafından emilen tüm enerji olduğu eşit enerji doğrusu üzerinden anlaşılmaktadır. $\mathrm{Bu}$ enerji doğrusu darbe enerjisi ile absorbe edilen enerji arasındaki ilişkiyi anlaşılabilir kılması için eklenen doğrusal bir eğim çizgisidir.

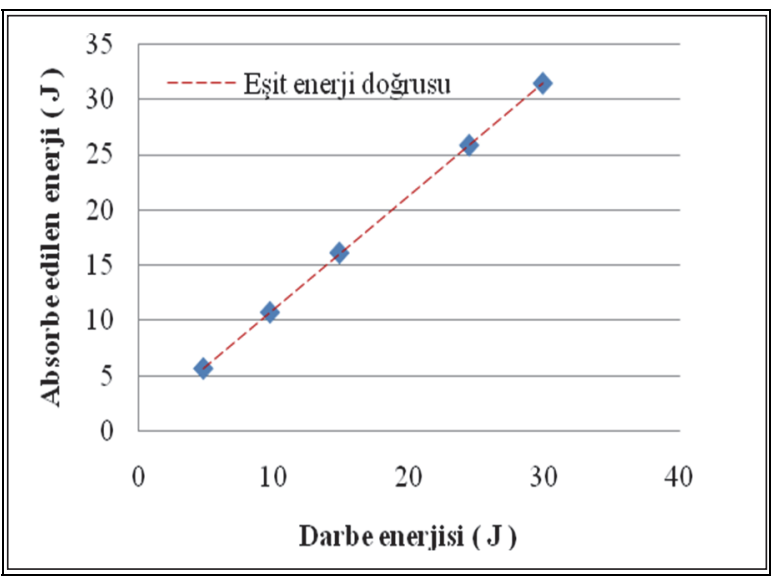

Şekil 6. Al köpüklerin enerji profili (Energy profile of Al foams)

\section{SONUÇLAR (CONCLUSION)}

Yapılan bu çalışmada Al/Si7 köpüklerin düşük hızlı darbe enerjileri altındaki penetrasyon davranışları incelenmiştir. Uygun gözenek morfolojisine ulaşmak amacıyla farklı köpürtme sıcaklıkları denenmiştir ve AlSi7 köpükler için $710^{\circ} \mathrm{C}$ sicaklıkta yapılan köpürtme işleminin uygun olacağı tespit edilmiştir. 
AlSi7 köpükler üzerine uygulanan darbe hızı arttıkça, penetrasyon derinliği de artmıştır. $30 \mathrm{~J}$ darbe enerjisinde ve $3 \mathrm{~ms}^{-1}$ darbe hızında alüminyum köpükte delinme meydana gelmiştir. Artan darbe enerjisi ile maksimum temas kuvveti artarken, çarpma ucunun köpük numunesine temas ettiği bölgede gözenek duvarlarının aşırı plastik deformasyonu sonucu temas kuvvetinin sıfıra düştüğü yani darbe enerjisinin tamamen sönümlendiği gözlenmiştir. Darbe hızındaki artış numunelerde hasar miktarını artırmış ve bu hasarlar gözenek duvarlarında çatlama, kırılma ve eğilme şeklinde olmuştur. Deformasyonun büyük çoğunluğu ise darbe ucunun alt kısmında meydana gelmiş ve yanal yayılma sergilememiştir. Darbe enerjisi ve penetrasyon miktarındaki artış ile absorbe edilen enerji miktarı artmıştır. $\mathrm{Bu}$ enerji miktarı darbe testleri sırasında kullanılan bütün enerjiyi kapsamıştır.

\section{KAYNAKLAR (REFERENCES)}

1. Gibson, L.J., Ashby, M.F., "Cellular solids, structure and properties (2nd)", Cambridge University Press, Cambridge (1997).

2. Çinici, H., “ Toz Toz Metalurjisi Yöntemi İle Al Esaslı Parçacık Takviyeli Sandviç Metalik Köpük Üretimi Ve Mekanik Özelliklerinin Araştırılması" Doktora Tezi, Gazi Üniversitesi Fen Bilimleri Enstitüsü, Ankara, 43-44 (2012).

3. Banhart, J., "Properties and applications for cast aluminium sponges", Adv. Eng. Mat., 2: 168 (2000).

4. Evans, A.G., Hutchinson, J.W., Ashby, M.F., "Multifunctionality of cellular metal systems", Prog. Mater. Sci., 43, 171-221, (1999).

5. Andrews, E.W., Gioux, G., Onck, P., Gibson, L.J., "Size effects in ductile cellular solids. Part II: experimental results", Int. J. Mech. Sci., 43, 701-713, (2001).

6. Paul, A., Ramamurty, U., "'Strain rate sensitivity of a closed-cell aluminum foam", Mater. Sci. Eng. A, 281, 1-7, (2000).

7. Paul, A., Seshachryulu, T., Ramaurty, U., "Tensile strength of a closed-cell al foam in the presence of notches and holes', Scripta Mater., 40, 809-814, (1999).

8. Olurin, O.B., Fleck, F.A., Ashby, M.F., “ Indentation resistance of an aluminum foam', Scripta Mater., 43 983-989 (2000).

9. Destefanis, R., Schafer, F., Lambert, M., Faraud, M., Schneider, E., "Enhanced Space Debris Shields for Manned Spacecraft", International Journal of Impact Engineering 29, 215-226 (2003).

10. Zhu, F., Zhao, L., Lu, G., Gad, E., "A numerical simulation of the blast impact of square metallic sandwich panels", International Journal of Impact Engineering 36, 687-699 (2009).

11. Hou, W., Zhu, F., Lu, G., Fang, D., "Ballistic impact experiments of metallic sandwich panels with aluminum foam core", International Journal of Impact Engineering 37, 1045-1055 (2010).

12. Kádár, Cs., Maire, E., Borbély, A., Peix, G., Lendvai, J., Rajkovits, Zs., “ X-ray tomography and finite element simulation of the indentation behavior of metal foams", Materials Science and Engineering A, 387-389, 321-325 (2004).

13. Ramachandra, S., Sudheer, P., Ramamurty, U., "Impact energy absorption in an Al foam at low velocities", Scripta Materialia, 49, 741-745, (2003).

14. Li, Q.M., Maharaj, R.N., Reid, S.R., "Penetration resistance of aluminum foam", International Journal of Vehicle Design, 37 (2/3), 175-183, (2005).

15. Lua, G., Shena, J., Houa, W., Ruana, D., Ong, L.S., "Dynamic indentation and penetration of aluminium foams", International Journal of Mechanical Sciences, 50, 932-943 (2008).

16. Sudheer Kumar, P., Ramachandra, S., Ramamurty, U., "Effect of displacement-rate on the indentation behavior of an aluminum foam', Materials Science and Engineering A, 347, 330-337, (2003).

17. Peroni, M., Solomons, G., Pizzinato, V., "Impact behavior testing of aluminium foam", International Journal of Impact Engineering 53, 74-83 (2013).

18. Gökmen, U., Türker, M., " $\mathrm{Al}_{2} \mathrm{O}_{3}$ İlavesinin Alüminyum Ve Alumix 231 Esaslı Metalik Köpüğün Köpürme Özelliklerine Etkisi”, Journal of the Faculty of Engineering and Architecture of Gazi University Vol 27, No 3, 651-658, (2012).

19. Uzun, A., Gökmen, U., Türker, M., "Toz Metalurjisi Yöntemi İle Üretilen Alüminyum Esaslı Metalik Köpükte $\mathrm{Si}$ İlavesinin Köpürmeye Etkisi', 5th International Advanced Technologies Symposium (IATS'09), 1003-1006, Karabük, Turkey, 2009.

20. http://www.instron.com/wa/library/StreamFile.a $\mathrm{spx} ? \mathrm{doc}=851$

21. Yu, C.J., Eifert, H., Baumeister, J., Banhart, J., "Metal foaming by a powder metallurgy method: production, properties and applications", Mat. Res. Innovat, 2: 181-188 (1998).

22. Kennedy, A.R., "The effect of $\mathrm{TiH}_{2}$ heat treatment on gas relase and foaming in $\mathrm{Al}-\mathrm{TiH}_{2}$ preforms", Scripta Materialia, 47: 763-767 (2002).

23. Mohan, K., Yip, T.H., Sridhar, I., Seow, H. P., "Effect of face sheet material on the indentation response of metallic foams", J Mater Sci., 42:3714-3723, (2007).

24. Shaw, M.C., Sata, T.," The plastic behavior of cellular materials', Int. J. Mech. Sci. 8, 469472, (1966). 